\title{
Management of marine species
}

\author{
P. Korringa \\ Feithlaan 8, 1985 GJ Driehuis NH, The Netherlands
}

\begin{abstract}
Marine fish and shellfish constitute important natural resources. Provided they are wisely exploited, they are not liable to exhaustion but continue to renew themselves. Wise exploitation requires sound management, and for such management one should be well informed about the factors governing the fluctuations in the stocks and about the costs of exploitation. A century of scientific fisheries research provided a wealth of information on reproduction, migration and growth of commercially important species of fish and shellfish and about the losses the stocks suffer through natural causes such as predation, diseases and parasites, and through the fishery itself. Such information is available for areas which are intensively fished. In fertile waters, the approximate growth increase of fish stocks is some $15 \%$ by weight year ${ }^{-1}$. If one were to harvest this $15 \%$ only, to be considered as interest on this natural capital, and to leave the capital itself untouched, one could go on fishing for ever. There would be no overfishing or stock depletion. For sound management we need not only ecological data but also information on economic fishery aspects, e. g. on size and power of the fleet, type of fish-finding apparatus installed, costs of netting and wages, fuel required per fishing trip, and on the capital invested. Further we need statistical information on the landings and on the proceeds. Such information is available in countries which participate intensively in fishing. Therefore, one would assume that governments which are well informed by their fishery biologists about fluctuations in stocks of fish and shellfish and by their economists on various aspects of the exploitation would apply sound management to ensure that fishing may continue for many years to come without depletion. A number of examples related to the North East Atlantic area, where intensive fishing is carried out and from where a wealth of scientific information is available, makes clear that cases of sound management are hard to trace.
\end{abstract}

Editorial note: Professor Dr. Pieter Korringa died shortly before the symposium. In his last letter he requested that his paper be read to the auditorium. After paying tribute to this distinguished colleague, Professor Dr. Otto Kinne read his paper. The texts of tribute and paper follow below.

\section{TRIBUTE TO PROFESSOR PIETER KORRINGA}

Dear Mrs Korringa!

Ladies and Gentlemen!

Colleagues and Friends!

It is with great sorrow and sadness that I stand here instead of a man distinguished by a long and successful career as a fisheries biologist: Pieter Korringa. He and I had agreed that he would present, at this symposium, an Introductory Paper, based largely on his own experience and concerned with the management of marine species. In spite of 
the fact that Pieter had been seriously ill for some time, he promised to do his best to complete the paper and to present it here personally, if at all possible. Pieter Korringa spent the last days of his life dictating the manuscript for this paper. He died on July 13, 1979.

Born on February 16, 1913, at Heemstede, The Netherlands, Pieter Korringa became a highly regarded, internationally prominent shellfish biologist and a distinguished teacher. For many years he served as Director of the Netherlands Institute for Fishery Investigations at IJmuiden. His major scientific accomplishments include research on shellfish cultivation and stock management of commercial fishes. Pieter Korringa was Extraordinary Professor at the University of Amsterdam. On numerous occasions he served his country as a delegate to international organizations.

His last major accomplishment was a four-volume treatise on the farming of marine organisms. Fishery sciences and marine ecology have suffered a great loss. We shall miss Pieter Korringa's leadership, advice and criticism.

Ladies and Gentlemen, $I$ would like you now to rise and stand for a minute in memory of Professor Dr. Pieter Korringa.

Thank you. Pieter Korringa, we shall always remember you in our hearts!

\section{INTRODUCTION}

The stocks of fish and shellfish constitute one of the natural resources man has exploited since time immemorial. It is always wise to keep an eye on the future and therefore to avoid wasteful exploitation of natural resources which might, in due course, lead to complete depletion. The great advantage of a living resource like a stock of fish or shellfish is that it can rejuvenate itself when carefully exploited so that sustained profitability is a realistic aim. Sound management is therefore a prerequisite just as in other industrial enterprises of our time. For such management one should have insights into the various factors which determine cost and magnitude of production and be able to identify limiting factors so that adequate measures can be taken to prevent stagnation in the development of the industry concerned. Foresight is required, expecially in our time, since the economic and social parameters are liable to change almost overnight.

The productivity of the sea, based on the carbon-dioxide assimilation by the phytoplankton, is not affected by the fishing industry, and in the more fertile waters one may count on an annual increment in weight of the fish stock of some $15 \%$, an increment simply due to growth of the fish. Were we to harvest this $15 \%$ - to be considered as the interest of this natural capital - and leave the capital itself untouched, we could expect to go on fishing for many years without observing signs of depletion or overfishing.

In most of the western countries facing the sea we nowadays have ample scientific information on growth and reproduction of commercially important species of fish, on the losses brought about by predation, diseases and parasites, and by the fishing industry itself. Further, we know the size of the fishing fleet, the power of the units and the gear used, so that we can draw conclusions about the fishing effort. Furthermore, there is as a rule reasonably reliable statistical information on the catches landed and on the proceeds made. We are also well informed about finance invested in the fleet, about the number of workers in the fishing industry and about the running expenses for fuel, netting, and wages. By combining the biological information on the fish stocks with the 
economic and social aspects of the fishing industry it should be possible to find a basis for sound fishery management. We could aim at the so-called "maximum sustainable yield," expressed in tons of fish, or lead the management to the maximum sustainable profit, expressed in monetary units.

Theoretically, sound management of the fishing industry must be possible, even in waters where more than one country operates. Whether such is the case can be concluded from the examples presented in this paper, dealing with the fisheries in the north-eastern Atlantic area, as well as fisheries in streams and lakes, estuaries and coastal waters, and the high seas.

I shall document here past developments and activities, as well as refer to the present state-of-the-art of the management of marine species by presenting 7 examples the oyster Ostrea edulis, the blue mussel Mytilus edulis, the brown shrimp Crangon crangon, the sole Solea solea, the herring Clupea harengus, the salmon of the River Rhine and the bowhead whale Balaena mysticetus - and a brief review of the development from Zuyder Sea to Lake IJssel. The major conclusions drawn are then presented in the final section.

\section{THE OYSTER}

There was a time when oysters Ostrea edulis abounded in the shallower parts of the North Sea. Very rich natural beds were found in the Firth of Forth, in the Dutch Wadden Sea, and in the waters of Schleswig-Holstein known as the "Fiskalische Austernbänke." Millions of oysters were fished there annually to be shipped to the cities where they were sold for what is now considered as a ridiculously low price. Entire shiploads of oysters were dispatched from the Firth of Forth to Zealand, where oyster dealers graded them and stored them in large sea-water basins prior to shipment to cities in Belgium and Germany. When a real net of railways spread all over Europe the market for such a perishable product as the oyster widened considerably and the demand increased rapidly. The oyster fishers gladly responded by increasing the intensity of fishing, and for a while business was good.

In the course of the 19th century the catch per day diminished alarmingly on the natural oyster beds of the North Sea, and compensation by putting more ships to work there seemed hardly possible. Apparently, the beds were overfished and some governments introduced a minimum legal size for oysters; they even closed the SchleswigHolstein beds for several years. Apparently these measures came too late, for revival of the formerly rich natural beds did not occur. At that time it was not understood why a natural bed could not restore its former richness when left alone. Today we realize what happened: a smaller number of adult oysters on the beds automatically means a smaller number of larvae produced in summer. Since only a very small percentage of the larvae reaches settling size, the number of larvae ready for settling must have been smaller still when the stocks of adult oysters became depleted. The larvae settle on hard and clean objects, a rare commodity on the sea bottom. The new shoots of the shells of adult oysters offer by far the best possibility for settling on natural beds. But, if there are fewer adult oysters, the chances of finding a natural collector are seriously reduced. Small oysters attached to the shells of adult oysters should be removed and scattered on the natural beds to reach marketable size in due course. But few fishermen will take the trouble to detach the young oysters from the shells of marketable oysters, for most probably, others 
might benefit from this extra work. Hence, many young oysters are lost, and from the moment adult oysters become so scarce that fertilization of all the eggs on the gills of the mother oysters is no longer ensured, the natural bed will collapse.

No living oysters can nowadays be found on the former natural beds in the Firth of Forth and in the Wadden Sea, though environmental conditions have hardly changed at all. This is the more deplorable since these populations of Ostrea edulis showed good larval development at water temperatures as low as $15^{\circ}$ to $16^{\circ} \mathrm{C}$, whereas the populations from Brittany and the Oosterschelde require $18^{\circ} \mathrm{C}$ at least, and the Wadden Sea oyster evidently could stand severe winter weather for a prolonged period. It was assumed for a long time that the populations showing such interesting qualities were irretrievably lost, but now there is some hope. Some years ago in the cadre of the Delta project, the Grevelingen - a body of salt water between the isles of Goeree-Overflakkee and Schouwen-Duiveland in the S. W. of The Netherlands - became cut off from the sea and from fresh water bodies further east. Oysters have occurred there since time immemorial, but reproduction was always very scanty. It was a surprise, therefore, that reproduction showed a sharp increase after communication with the sea was severed, though the number of mother oysters remained low. Evidently larval survival is much better under the new conditions, presumably because predators such as anchovies, ctenophores and the like, which devour millions of pelagic oyster larvae, can no longer enter the Grevelingen body of sea water.

Recent evidence gives hope for the future: the unusually low water temperatures in the cool summer of 1978 led to a complete failure of spatfall in the Oosterschelde, but in the Grevelingen good numbers of spat could be observed on the experimental collectors, despite the fact that water temperatures stayed well under $18{ }^{\circ} \mathrm{C}$ (the critical level for the Oosterschelde oysters). Moreover, the winter of 1978-1979 was very long and cold with ice on the water for many weeks in succession. Despite these unfavourable conditions, the young oysters in the Grevelingen did not suffer appreciable losses. One may surmise that the wild Grevelingen stock shows the same excellent qualities as the former Wadden Sea and Firth of Forth oysters: larval development at low water temperatures and hardiness in severe winters. The Dutch Government, in cooperation with the oyster farmers of Yerseke, is attempting to protect this stock of oysters, and to avoid its becoming mixed with the Oosterschelde stock, in an effort to develop the salt Grevelingen basin into a nursery ground for oysters from which the juvenile oysters can later be transferred to the Oosterschelde plots for further growth and fattening. Cool summers and severe winters, which repeatedly interfere with the development of the oyster stocks, will then, hopefully, no longer endanger the Dutch oyster industry. It is here, in the cooperation between the government and the oyster farmers that real management begins, after hundreds of years of mismanagement of the natural oyster beds. Oyster farming on the plots of the Oosterschelde is quite a different thing, a case of private enterprise by oyster farmers operating on plots leased from the government.

\section{THE BLUE MUSSEL}

Natural beds of the blue mussel Mytilus edulis occur on many a site in the shallower parts of the North Sea. They are, as a rule, only of limited interest to the fishing industry. Mussels may settle on various levels, but only in the intertidal zone is the survival rate 
good, since their main enemy, the seastar Asterias rubens, cannot attack them there as it is liable to predation by sea-gulls. Mussel seed which settled in deeper water often disappears in a rather short time. The tidal zone is, however, not the best place for rapid growth and fattening, since water rich in plankton reaches the mussels here only intermittently. The mussels on the beds in the intertidal zone - those attached to breakwaters included - are generally of irregular size and age and rather poor in the quality of their edible parts and, therefore, of little importance as human food.

Still, a natural mussel bed constitutes a biologically very rich resource. Here one finds up to $10 \mathrm{~kg}$ of mussels per square metre, a density of animals one will rarely find elsewhere. We should, however, beware of making comparisons with the situation on the land, for example, with the number of cows on a given pasture. This not only because mussels consist of only about $25 \%$ of meat, wet weight, but also because they do not live from the food produced on the acreage they are actually growing on, but rather from the phytoplankton produced in a far larger area and carried to them by the tidal currents. A comparison with a modern bio-industry of chickens or with an apartment house full of people is more realistic.

What use have we made of this rich resource? Long ago fishermen from Zealand found that transfer of mussels from natural beds to sites with both sufficient shelter and plenty of food - but where they would not settle naturally - could lead to rapid growth and fattening and thus, in much shorter time than is observed in oysters, to a product fit for the market and for the human table. It took, however, a long time before this practical experience could be applied on larger scale. One had first of all to be sure that one could harvest the mussels transferred to the fattening grounds, oneself, that is, that other fishermen would not benefit from the work. Therefore, real development of a mussel industry became only possible when the government leased plots to prospective mussel farmers and organised proper police patrol to ensure that nobody would trespass on other people's grounds. This happened about 100 years ago, and since then the Dutch mussel industry has developed properly. Some management by the government took place: to avoid wasteful exploitation, the natural mussel beds were closed and only opened for a limited number of days or weeks when the governmental advisors thought it wise to do so. Then the mussel farmers from Zealand could get their boat-loads of mussel seed from the natural beds in the Wadden Sea to plant them on their plots in the Zealand waters; after 1950 they also used newly installed plots in the western section of the Dutch Wadden Sea, from where one nowadays harvests $70 \%$ of the total production of marketable mussels, which amounts to some $100000000 \mathrm{~kg}$ per year.

Formerly, mussel seed was also fished on the natural beds in the Wadden Sea and in the northern part of the Zuyder Sea as feed for duck farms in the centre of the country and, at the termination of World War I, also large consignments of wild mussels were shipped, from the natural beds in the Wadden Sea to the hungry people in defeated Germany, but it was clear that this market would only be a temporary one considering the poor quality of the product.

In conclusion, a certain amount of management is applied to the natural mussel resources in The Netherlands: keeping the natural beds closed and well guarded, inspecting the beds for development of mussel seed, and advising the government to open the beds for the fishery of mussels designed for the farming procedure only during well-defined periods. 


\section{THE BROWN SHRIMP}

The brown shrimp Crangon crangon abounds in the coastal waters of the eastern shore of the North Sea, from the Straits of Dover to Jutland. It is rather small, up to $6 \mathrm{~cm}$ long, but of an exquisite flavour. A fishery for brown shrimp developed in due course along the usual empirical lines, not guided by scientific advice or official regulations; once it had been established, the fishermen claimed that it was their lawful right to make a living that way. First one fished from the beaches, and horses were often used on the Belgian section of the coast; later boats came into use starting with sailing vessels, then boats equipped with engines. These operated a long time with trawls kept open by doors, but in due course the fishermen found the beamtrawl more efficient. It is only logical when fishing for creatures as small as brown shrimp that one uses fine-meshed nets although a by-catch cannot be avoided. However, it took a long time before one learned more about the practical importance of the discards, and of the impact of the destruction of creatures other than shrimp on the fishery elsewhere. Sets of shaking sieves were in use on the shrimpers to produce a marketable product free of alien objects, and larger fishes were taken out by hand before one proceeded to boil the shrimp on board. It was not until a biologist of the "Netherlands Institute for Fishery Investigations" undertook a more detailed study on the brown shrimp and its fishery that we realized how many young flatfishes, especially plaice and sole, could be encountered in the catches at certain times of the year, especially in the Wadden Sea and in the Zealand estuaries, the most important nursery grounds for North Sea flatfish. Of course, the fishermen must have seen this, but did not worry about it, since they fished exclusively for shrimps, whereas other fishermen, often from other sections of the country were after flatfish. The flatfishes in the by-catches were small, but often extremely numerous. Sufficient information was available on growth and natural mortality of these small flatfishes to allow calculation of the deleterious effect the brown shrimp fishery exerted on the flatfish fishery elsewhere in the North Sea. It turned out that the damage done to the recruitment of sole and plaice, expressed in terms of money, exceeded by far the proceeds of the shrimp fishery.

For a fishery administrator such information is unwelcome news, for one cannot prohibit a fishery which for centuries has provided a living to many fishermen. Were the causal relation between the gathering of brown shrimps and flatfish known prior to the development of a professional shrimp fishery, then it would have been wise to decide to protect the flatfish in an effort to exploit the natural resources as rationally as possible, but it is - for a fisheries administration - almost impossible to cut short an already existing fishery with a long tradition. This would not only lead to fierce protest from those who make a living that way, but would also upset public opinion and would lead to strong opposition in Parliament, despite the economic logic of such a decision.

What happened in this case? One could not simply ignore the scientific evidence, especially not since the sole fishery had become the major moneymaker in the Dutch fishing industry. Biologists and specialists in fishery techniques concentrated their efforts on this problem and found in due course two ways to reduce the drastic losses suffered by the young flatfishes. The first was introduction and adaptation of a so-called sieve-net, first developed in France, which led under certain conditions to large-scale escape of flatfishes without any reduction in the shrimp catches. But more important still 
was the development of an ingenious apparatus to be installed aboard which could sieve the catch in water in such a way that both young flatfishes and juvenile shrimp return undamaged, alive and kicking, to their natural environment. The Dutch Government decided to promote the introduction of this apparatus on the shrimpers of the Dutch fleet and subsidised its purchase. It could, however, not compel all shrimp fishers to buy this special equipment and to use it, but since the fishermen observed that it is also a laboursaving device, there has been a general tendency to introduce it on those ships which lend themselves to it. This way the deleterious effect of the shrimp fishery on the flatfish fishery elsewhere in the North Sea can be reduced to such an extent that both fisheries can reasonably co-exist.

\section{THE SOLE}

Of all the fishes caught in the North Sea the sole Solea solea brings by far the highest price per $\mathrm{kg}$. Contrary to the events in most other species of appreciable commercial value the sole catches made in our time are definitely higher than those made earlier in the century. One would suppose that the larger and faster ships and the more efficient gear would explain the greater sole landings in post-war years, but there is scientific evidence, based on egg-counts in the plankton, which indicates that the stock of North Sea sole must really have been of lesser magnitude earlier in the century.

The Dutch fishing industry, specialized in export of fresh table fish, has concentrated its efforts more and more on catching sole. Specialized units were built for this purpose. The best catches could be made shortly after sunset when the sole begins to forage, and

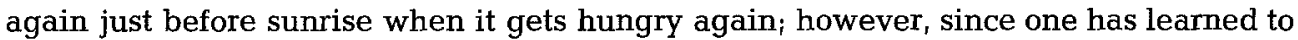
use whole series of tickler chains, which chase the sole out of the sand any time of the day, the sole catches are no longer limited to the dark hours of the night.

More and more units were built specially for the sole fishery and in the mid-1950s the day came when the financial proceeds of the sole fishery surpassed those of the herring fishery, which had long predominated in the Dutch fishing industry. The North Sea sole fishery became more and more a Dutch business, and now 80 to $85 \%$ of the sole caught is taken by Dutch vessels. This would make it possible to develop a sound management for this fishery. International agreement would hardly be necessary, for all measures taken would operate practically exclusively on behalf of the Dutch fishery.

What happened? Scientific investigations made clear that reproduction shows sharp fluctuations in the sole, sharper than in many other fish species. Though the number of eggs produced during the spawning season will not show major deviations from the average, the success of reproduction varies largely. Poor years, in due course leading to at most a modest recruitment, alternate with good years producing excellent catches a few years later. Unfortunately really rich year classes seem to occur only about once in ten years. Very great numbers of juvenile soles were, for instance, produced in the years 1947,1958 , and particularly 1963, and 1969 gave a reasonably good birth rate. About $2 \frac{1}{2}$ years later the first "recruits" make their appearance in the catches. The question of which factors are to be held responsible for success or failure in reproduction is still far from being answered, but even if one knew one would still have to wait and see what nature has in mind.

If a really good year class has grown to recruitment size the fishermen will notice this by a sharp increment in the percentage of juvenile soles in the catches. Since the 
market for soles is excellent in many European countries big money will be made when the catches are good. Therefore a rich year class incites the fishermen to enlarge their fleet, which shows consequently neat peaks roughly $4 \frac{1}{2}$ years after the birth of each rich year class. The 1973-1974 peak in the number of fishery units is, however, higher than could be expected on the basis of the size of the 1969 year class only, but easy terms for getting money from the banks worked out that way. The money made is not only invested in more ships, but also in bigger and stronger ships for this same type of fishery. A bigger ship with a stronger engine makes better catches, though it also requires greater investment and higher costs for fuel and gear. Fishermen are above all keen on great catches and therefore tend to build ships which are bigger and stronger than those of their colleagues. This would not matter if at the same time one reduced the number of units in the sole fishery, but neither the fishing industry itself, nor the government has the power to achieve this. The final result is a fleet too big and too strong for the sole there is to catch. Surely, the stock of soles does not keep pace with the size of the fleet. The fishermen saw the catches made per hour fishing decline alarmingly and tried to compensate this by building still bigger and stronger ships. For an individual fisherman this may seem to help, but the total catches will not go up. On the contrary. Now the banks which offered money on too easy terms begin to realize that brand-new ships specialized for the sole fishery are not such a good guarantee for their money when there is not enough fish to be caught to cover the running expenses.

Scientific evidence shows that bigger catches could be made by a further increase in the mesh size of the trawl nets, though this would initially lead to a reduction in the catches, but also that the Dutch cutter fleet specialized for the sole fishery is much too strong. With a fleet about one third of the present size one could catch the same total tonnage of sole as today. But the question arises, who is going to give way and how one can prohibit the building of yet another ship for the sole fishery. A smaller fleet landing the same annual catches as today would greatly increase the remuneration of each individual ship, but how could one reach this goal on the basis of the present fishery laws and regulations? The scientists know that even a fleet as large as today will not exterminate the North Sea sole and that a depleted stock may in due course recover when the fishing intensity is finally reduced because one loses too much money operating in the present way. But they are not too sure that nature will readily produce a good stock of soles once the fishing intensity would be drastically reduced. There is such a thing as the "stock-recruitment relation" which means that recovery of a stock will take a long time once the total number of eggs produced during the spawning season has dropped below a critical level. The biologists studying the North Sea sole are afraid that this critical level is already operating, and therefore dare no longer prophesy that a good year class will occur at least once in ten years.

What management would be conceivable to safeguard the future of the Dutch sole fishery in which so much money has been invested and for which there is not enough fish?

\section{THE HERRING}

The herring fishery predominated in the North Sea for many years. Several countries participated in it, the usual gear being the drift net set out at sunset. The mesh size was such that only adult herring Clupea harengus, rising to higher water layers in search of 
food in the dark hours of the night, would get entangled by its gill covers. In the period between World War I and World War II one observed symptoms of serious overfishing in demersal species such as flatfishes and gadoids in the North Sea, but not in the herring fishery. Samples of herring caught in the drift nets appeared to consist of several year classes, sometimes up to ten. Thus the existing fluctuation in the strength of the individual year classes was hardly reflected in the size of the catches. When it was decided in 1946 to introduce international regulations to prevent overfishing in the North Sea, pelagic fishes such as herring and mackerel were considered to be so plentiful that they needed no protection at all. No legal minimum size was considered necessary for the herring.

Drift netting revived after World War II, but in addition fishermen began more and more to use fine-meshed trawl nets to catch the herring close to the bottom during daylight hours. This became possible by use of boats with stronger engines which could move the net with a speed faster than that of herring trying to escape by swimming. Gradually the trawls caught more and more herring and finally drift nets became obsolete in the Dutch fishery. This development was furthered by the introduction of electronic fish-finding equipment which made it possible to locate the herring schools with considerable precision. Since herring schools are sometimes observed in midwater, a pelagic trawl was developed to chase the herring wherever it occurred.

This development led to a noteworthy increment of the fishing intensity for herring, and thereby to a reduction of the number of year classes found in the catches. The intensive fishery made it virtually impossible for the herring to reach an age of 10 to 15 years, as it could with some good luck in earlier times. In reality the catches made in the last few years consist virtually exclusively of the year class which is being recruited, herring of three years old whereas herring of earlier year classes represent only a minority in the catches. The stock which spawns in the Channel late in the year and congregates along the eastcoast of England in late summer and early autumn suffered more from intensive trawling than any other stock of North Sea herring and lost thereby much of its former importance.

But perhaps the prolific North Sea herring could have coped with this development if it had not been attacked from two sides by an industrial fishery. First the so-called Bløden fishery, taking juvenile herrings in the German Bight to be reduced to fish meal in Danish and German plants, and next the powerful attack by the newly developed Norwegian fish-meal industry in the 1960s. Technical improvement made it then possible to haul huge purse seines with the aid of a power block and thus entire schools of herring, traced by electronic fish-finding equipment, could be caught. The so-called Atlanto-Scandian herring, the northernmost stock, consisting of large-sized individuals, migrates in winter to some sections of the Norwegian coast to spawn. Norwegian fishermen used to land appreciable quantities of this herring of which the greatest share was reduced to fish meal, the market for direct human consumption being very limited in Norway. Now the introduction of the power block made it possible to expand the fishery on this herring stock, thought to be inexhaustible. The Norwegian Government backed the expansion of the fish-meal industry and soon huge quantities of herring were landed. However, the stock was not inexhaustible at all, and dwindled to insignificance within a few years towards 1970 (Fig. 1). Too much money had been invested in ships and fishmeal plants to stop the ill-planned Norwegian industrial fishery. Therefore, one went 


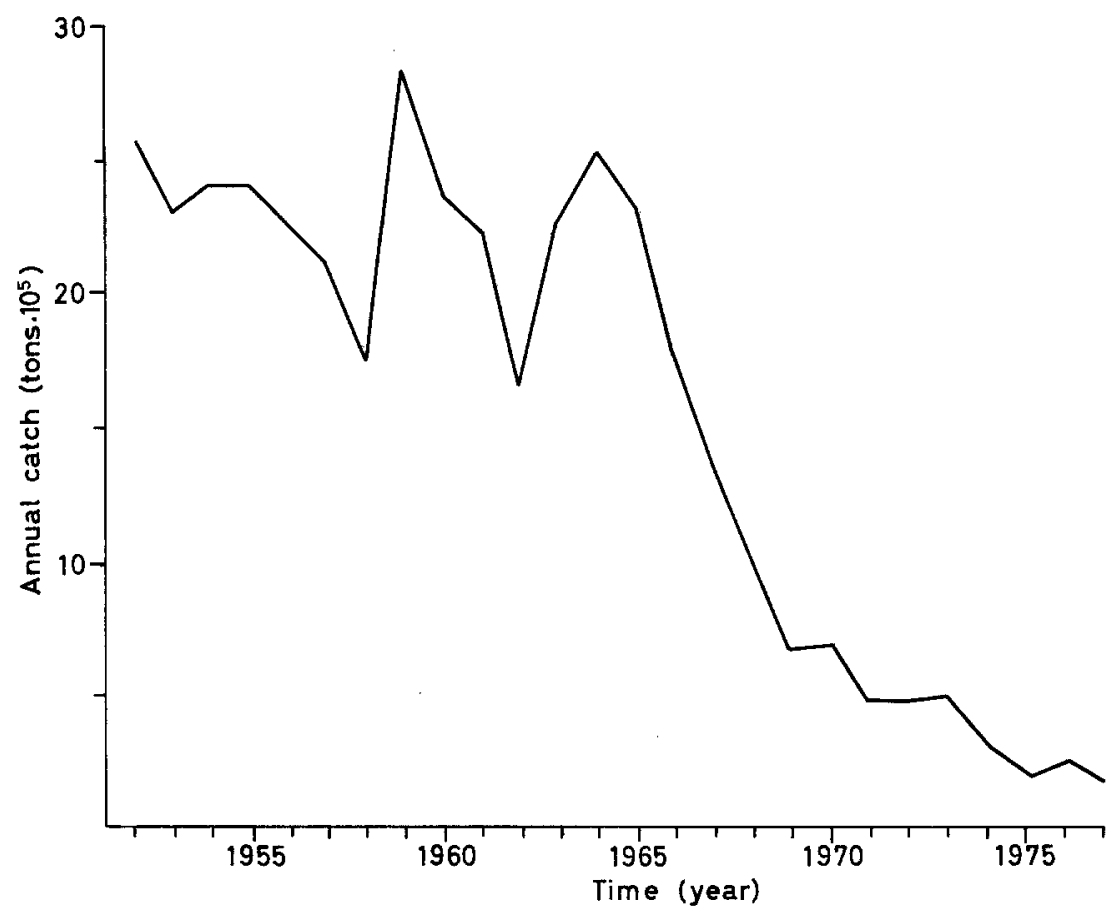

Fig. 1. Dramatic events in the stocks of North Sea herring under the influence of drastically increased fishing intensity

with all force after the mackerel and after the North Sea herring proper. It was especially this latter development which brought the North Sea stock of herring down to a particularly low ebb. The International Council for the Exploration of the Sea warned the North-East Atlantic Fisheries Commission that too heavy a toll was levied of the North Sea herring and that only drastic measures could safeguard the future of the herring fishery. The Council noted that the 1973 year class was of reasonable magnitude, able to secure a good offspring, but that later year classes were poor or even extremely poor. Therefore, the Council advised that fishing 1973 year class be abstained from in an effort to offer the North Sea herring an opportunity to revive its stocks. The North-East Atlantic Fisheries Commission discussed this advice seriously, but the fishing industry refused to follow it because the herring were urgently needed. All one did at this very late moment was to introduce a minimum legal size for herring, which meant that the Danish fishmeal industry would no longer be allowed to fish purposely for juvenile herring in the North Sea. It could, however, fish for sprat, and among the sprat one often finds juvenile herrings as a by-catch.

A quota system was introduced by the North-East Atlantic Fisheries Commission for all species of commercial importance including herring. However, the countries which traditionally fished for herring destined for direct human consumption saw with dismay that the breakdown of the overall herring quotum over the various nations led to by far the greatest share for Norway, based on the magnitude of its catches in recent years. Many countries, among them The Netherlands, claimed that high priority should be 
given to fishing for direct human consumption, but on what basis could one compel a given country to eat the fish it catches instead of feeding it to pigs and chickens after reducing it to fish meal?

The future seems very gloomy for the North Sea herring fishery. The advice of the scientists to give the 1973 year class a chance to produce offspring was flung to the winds and hence this year class was wiped out by the 1976 fishery. Later year classes are so poor that one can hardly expect a revival of the stocks, even when they are completely left in peace. The danger is then that sprat takes over from the herring in the North Sea, in the same way the anchovy took the place of the over-fished sardine in the coastal waters of California. Stocks of demersal fishes such as flatfishes and gadoids will not run the risk of being fished down to such a low ebb as schooling pelagic fishes such as herring and mackerel. With modern fish-finding equipment and modern gear one could trace and catch the very last school of these pelagic fishes, whereas the demersal fishes, which do not concentrate to such an extent, will be left alone when the catch per unit of effort drops below a given level.

Though all countries fishing for herring in the North Sea are seriously concerned about the present state of the stocks, it seems hardly possible to reach agreement leading to sound management. There is no sound legal basis to stop the industrial fishery and there are no international funds to buy it out. Every ton of juvenile herring taken as a bycatch reduces the future stock of adult herring by four tons - the natural mortality taken into account - but only a strict control could enforce obedience to limiting the by-catch of the industrial fishery to the tonnage agreed upon. Countries traditionally fishing for herring destined for direct human consumption are very hesitant to accept regulations restricting their catches, as long as the real cause of all the trouble in the herring world, the industrial fishery, has not disappeared and as long as the quotas are not based on the former catches for human consumption only.

\section{THE SALMON OF THE RIVER RHINE}

Once the River Rhine teemed with salmon Salmo salar. In the years following 1869 , for which reliable statistics are available, 50000 to 60000 salmon per year were caught in its downriver section. Almost all were big fishes weighing some $10 \mathrm{~kg}$ each. Only $14 \%$ of the catches consisted of males participating for the first time in the run, weighing some $2 \mathrm{~kg}$ each. The Kralingse Veer near Rotterdam was then the big market for salmon. Huge nets were used to catch the migrating salmon; they were operated either from some type of raft or from a fixed installation on the river bank. Originally, the nets were drawn in by hand, but in the shore installations one could make use of a horse-mill for this heavy work. In due course, it was decided to make use of steam power to draw in the nets. This made it possible to use still larger nets, blocking off the river hermetically. Since then, three such large nets were operated in turns, but few of the migrating salmon got a chance to escape. The catches increased sharply with the introduction of steam power and in the years following 1880 one could often bring more than 100000 salmon to the market. But this could not last. Too few salmon could reach the spawning grounds in the upriver tributaries. First the percentage of small salmon went up, next the total catches dropped alarmingly.

In the year 1885 Germany, The Netherlands and Switzerland concluded the so- 
called "Salmon Treaty," which led to interruption of fishing for salmon during the weekends and during a close season late in summer, but the expected and forecasted return of large catches of salmon from the River Rhine did not occur. In fact, the measures taken came too late and, moreover, overfishing was followed by the construction of more and more weirs and barrages for shipping and hydro-electric stations, which made it impossible for the salmon to reach their spawning grounds in the tributaries. Here and there fish passes were constructed, but they were evidently not of a design appreciated by the salmon, and those fishes which did manage to bypass the barrages found their habitat deteriorated: instead of water running swiftly over gravel beds, the salmon found above the barrages almost stagnant water with a muddy bottom, totally unsuitable as spawning ground. Then came the rapid industrial pollution of the water of the River Rhine which gave the last few salmon caught a nauseating phenol flavour (Fig. 2).

Was there no proper management at all? Evidently not. It is incredible that the disastrous results of hermetically blocking off the river by a series of nets hauled with steam power were not foreseen and forestalled. Towards the end of the nineteenth century it was decided to release hatchery-reared salmon in an effort to revive the once so prosperous stock, but though much money was spent this way the goal was not realised. A combination of overfishing, barrages and water pollution had deteriorated the situation for the salmon so drastically that a revival of the stock had become impossible. Of course, one can conceive of international measures to check the serious industrial pollution of the River Rhine, now virtually an open sewer. Such measures would be costly although beneficial for other interests too, but who would suggest taking away the weirs and barrages to restore the salmon's spawning grounds in the upriver areas? For economic reasons it seems much wiser to rely on purchasing fresh salmon from Norway, where salmon are reared to consumption size in netting pens placed in well-sheltered fjords.

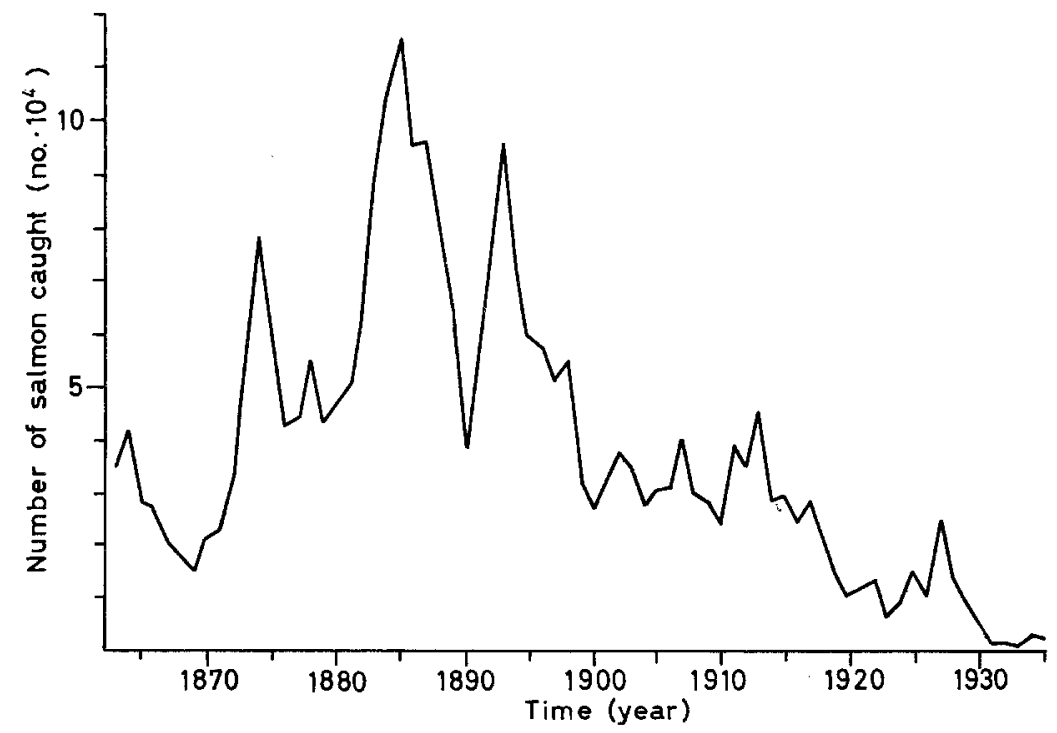

Fig. 2. Total salmon landings from downriver sections of the Rhine and Meuse 1863-1935 


\section{THE BOWHEAD WHALE}

Between the years 1594-1597 three now famous voyages were undertaken by Willem Barents, Jacob van Heemskerkck and Jan Cornelisz. Rijp. They were ordered to seek a new route to Japan, China and the Indies, since the traditional route via the Cape of Good Hope was rather dangerous because of the war with Spain. It was on the third voyage that they came as far as the Isle of Nova Zembla where they stayed during the Arctic winter in a hut made from the ship's timber. The survivors returned the next spring in open boats to the inhabited world. They had not found an alternate route to the Indies, but they reported on large schools of whales they had observed in the northern waters, especially around the Isle of Spitsbergen (Svalbard). It was a type of whale which differed somewhat from the Atlantic Right Whale, for which the Basques and the British had been hunting for many years. Its head was very high, and the baleens or whalebones were correspondingly long.

It took some time before practical use was made of this information, but in due course ships sailed north to catch whales. British and Dutch ships arrived almost simultaneously, in later years followed by ships from other nations. After some dispute and quarrelling each country made use of its own bay to operate a land station for whaling. The Dutch settlement was appropriately called "Smeerenburg".

The demand for whale oil and baleens was great at that time and soon prosperity spread among those directly or indirectly engaged in whaling in the arctic waters. But it would not and could not last, because fishing was so intense that nature could not compete with these losses through reproduction and growth. One did not think in such terms at that time but it was noted that the number of whales in Spitsbergen waters declined dramatically and that it became difficult to operate from a land station. At that time, the Dutch used a land station on the Isle of Jan Mayen. But here too whales disappeared in due course. The fishing pattern had to be changed from using a land station to pelagic whaling though the latter method was more cumbersome and produced a whale oil of inferior quality since boiling operations had to be carried out after return to the home country. The whalers did not believe that they were to blame for the decline of the stocks. They assumed that whaling just scared the whales which then withdrew to inaccessible ice fields further north.

The reality was, however, that bowhead whales Balaena mysticetus became more and more scarce, even in the waters west of Greenland, and arctic whaling came to an end late in the 18th century when it was no longer remunerative to hunt for bowhead whales. Narratives like that of the whales' "Frankendaal" give a good impression of the situation in the years 1786-1787. Whaling was stopped because it had become an impossible enterprise from the economic point of view, caused by dropping prices for whale oil and baleens, and by the great scarcity of whales.

For a time it was thought that the bowhead whale was extinct or would soon become so as it must have been hard for the whales to find each other in the mating season when the population was so very scanty. But that did not happen. There are still some bowhead whales in the Arctic Ocean. On advice of the International Whaling Commission it was decided to protect the bowhead whale. This was an easy decision to make since exploitation of this stock was already completely impossible from the economic point of view. An exception was made for the Eskimos with their long tradition of whale hunting. 
They still catch a bowhead whale occasionally but, unfortunately, nowadays switch over from their old primitive gear to more modern equipment. This will make it all the more difficult for the reduced stock of bowhead whales to recover.

A similar sad story, based on lack of management, could be told about antarctic whaling in our time. When the demand for whale oil was great after the Second World War, several countries sent large factory ships to the Antarctic Ocean to hunt for blue whales and fin whales. In due course the catch per day diminished, but the whalers found quite a few explanations for this fact other than that it could have been caused by their own activities. There was an International Whaling Commission, advising the governments involved on the best way of operating in antarctic waters. The scientists in this commission had the duty to demonstrate as accurately as possible what effect fishing had on the whale stocks. Ideal management would be harvesting the rent of this natural capital alone, taking the tonnage added to the stocks each year by growth and reproduction. But the scientists could not agree on the best way to determine the age of the whales, and thus could not produce reliable figures on growth and reproduction. In such cases governmental authorities are inclined to listen to industry rather than to quarrelling scientists. The whaling industry was not willing to reduce its catches in such a way that it could be considered as an economic sacrifice and thus hunting went on indiscriminately. The result is well known: the stocks showed signs of depletion which made economic exploitation more and more difficult, especially when the price of whale oil dropped dramatically by an increasing production of vegetable fats in tropical countries. Several countries stopped antarctic whaling for economic reasons, but the USSR and Japan continued. True management is at present out of the question.

Experts from FAO informed us some years ago that the fin whale would require 40 years, the blue whale at least 80 years to recover their stocks to a level of economic importance, provided we stopped whaling completely now. This is not an effort of management but just a kick in the air. No government is willing to impose severe restrictions on its industries on behalf of such a long-term possible benefit. Government officials and political leaders are rather thinking in terms of beneficial developments within their terms of office. Therefore we cannot hope for sound management of whale stocks. On the other hand, complete extermination is not to be expected. Long before that time it will become economically impossible to continue whaling, in any case where large factory ships are used.

\section{FROM ZUYDER SEA TO LAKE IJSSEL}

In the year 1932 the communication between the North Sea and the Zuyder Sea became cut off by the completion of a huge enclosing dam. Henceforth, it would be impossible for the stock of spring-spawning herring to reach its low-salinity spawning grounds in the southern part of the old Zuyder Sea, and for the anchovy, the money maker among the Zuyder Sea fishes, to find the warmer waters prevailing there in fine summers. The entire pattern of the fishery would change. The River IJssel, a tributary of the Rhine, discharged so much fresh water that it took only a few years to transfer the old brackish Zuyder Sea into a lake containing low-salinity water, practically fresh enough to drink. At the same time it brought ample nutrients from the hinterland to which were added the discharges of sewers from the cities around the old Zuyder Sea, Amsterdam included. As could be expected from this pattern the water of Lake IJssel soon revealed a 
rich plankton and bottom fauna on which fishes adapted to low salinities could thrive. It could be expected that cyprinids such as the bream (Abramis brama) would thrive there, together with the ruff (Acerina cernua), a small member of the perch family, and that the smelt (Osmerus eperlanus), being very euryhaline, would survive here, possibly as stock of rather small individuals, but all these would hardly be of any direct value for the fishery. It would be of considerable interest if the common perch (Perca fluviatilis) and the pike-perch (Lucioperca lucioperca) would thrive in the new Lake IJssel, for these fishes are welcome on the market. One felt quite sure that perch stock would soon increase, but for the pike-perch, originally a non-indigenous species, some doubt seemed justified. Above all one hoped for the development of a rich stock of eels, the most valuable of the fresh water fishes occurring in the waters of The Netherlands. The elvers, born in the Sargasso Sea, had to make their entry from the north and would find the enclosing dam in their way. How would they tackle this obstacle? It is true that two groups of locks had been constructed in the enclosing dam which would facilitate their passages if they could find them, but the engineers in charge insisted on keeping the saline waters from the open sea away from Lake IJssel. Initially the elvers passed the locks in the same way as the ships for which they had been constructed, but on the basis of scientific investigations an ingenious system of nocturnal manipulations with the doors of the locks was developed in due course; this led to large-scale passage of elvers into Lake IJssel without any intrusion of salt water. Would the elvers stay in Lake IJssel or would they make their way into the hinterland? Fortunately, many juvenile eels stayed in Lake IJssel, which was richer in food than most of the waters further upstream.

The transition from Zuyder Sea to Lake IJssel would offer an excellent opportunity to change the pattern of the fishery in such a way that one could speak of a rational exploitation of the natural resources. A bill had been passed which facilitated financial compensation for those of the old Zuyder Sea fishermen who would lose their living. Therefore, there was a good opportunity to set up an entirely new pattern for the fishery in Lake IJssel. If the eel was to become the leading species, it would be wise to catch silver eels preparing for migration to their spawning grounds, for then they reach their highest market value. This is the system so effectively used in the Lagoon of Comacchio in Italy. For a variety of reasons the planning turned out differently. Catching eels exclusively as silver eels would not only reduce the fishing sesason to a few months a year, whereas there was a good demand for eels throughout the summer season, but would also be exclusively beneficial for those fishermen who operated in the migration routes of the eels, depriving fishermen elsewhere around the Zuyder Sea from catching eels. Moreover all this happened during the ill-famed depression years and the Ministry insisted on keeping a large number of small fishermen in the fishery rather than to operate with a smaller number of stronger units. It was even suggested making use of sailing vessels only, and to abstain from using engine power for reasons of economy.

What happened? The eels found enough food in Lake IJssel. Some were caught in the immature state with a variety of gear, among which was the traditional fine-meshed eel-trawl, used during the dark hours of the night. The eels which could escape from the various gears of the fishermen metamorphosed and tried to make their way to the ocean along certain migration routes. At that time only fyke nets with long leaders could be used to catch the swiftly travelling silver eels. Scientific research revealed that there existed a certain relation between the magnitude of the immigration of elvers in a given 
year and the success of the silver eel fishery some seven years later. This made it even possible to forecast the results of the silver eel fishery. To prevent the immature eels from being caught at too small a size, a minimum legal size of $28 \mathrm{~cm}$ was introduced; to prevent too high a fishing intensity for immature eels no engines stronger than $25 \mathrm{hp}$ were allowed in the fishing boats operating in Lake IJssel. The advice to stick to sailing vessels only was not accepted by the fishermen, for they soon found out that engines would allow them to operate in almost any type of weather and would lead to better economic results.

It was no easy matter to enforce the minimum legal size for immature eels, but the $25 \mathrm{hp}$ rule seemed to work quite well. Around 1960 the eel fishery in Lake IJssel did not seem to flourish as well as before; in particular, the fishery for silver eels showed much poorer results than forecast on the basis of the immigration of elvers. Scientific research carried out by the Netherlands Institute for Fishery Investigations revealed the cause of the decline. The lack of silver eels had to be ascribed to an increased fishery with the eel trawls, this not because more ships participated in the fishery, but rather because clever fishermen had learned to abuse the $25 \mathrm{hp}$ rule in several ways. A faster boat appeared to lead to greater catches and better proceeds. Other fishermen saw this happen and soon followed the example, though dangerous and illegal. It soon turned out that some of the boats worked in reality with a horse power of 60 to 80 instead 25 . No small wonder that the silver eel catches had declined so drastically! The scientific report also made clear that the intensive trawl fishery for immature eels made it virtually impossible for the stocks of perch and pike-perch to develop, since too many juvenile specimens found an untimely death in the fine-meshed nets.

The report led to a serious clash in the Ministry and even to dismissal of its Director of Fisheries. A special commission was set up in which both professional fishermen and sport-fishermen were duly represented. It could only corroborate the allegations of the biologists that the fishing intensity had gone up alarmingly since the $25 \mathrm{hp}$ limit became grossly abused and the $28-\mathrm{cm}$ minimum legal size for eels was not always observed. The professional fishermen even admitted that they often fished for eels in the forbidden coastal zone, the spawning and nursery grounds for perch and pike-perch, though duly delimited by lights, and that the installation of radiotelephones on their vessels made it possible to keep each other informed on the whereabouts of the patrolling policevessels. No small wonder that many pike-perch nests were destroyed and that the trawls made a terrible slaughter of the juvenile perch and pike-perch. Something had to be done to restore the former productivity of Lake IJssel. Reduction of the fishing intensity, especially of the trawl fishery, seemed imperative, but one hesitated to take such a drastic measure and considered for the time being a step-by-step reduction of this fishery.

It was a political move, set going by the Organization of the Sport Fishery, which led to a break-through. Based on a passage of the report of the commission, indicating that measures to protect the young pike-perch would be especially effective when a rich year class would be forthcoming, they used the information that the juveniles born in the year 1969 would be numerous to take action. This move led to a complete prohibition of the nocturnal trawl fishery with fine-meshed nets, beginning with the 1970 season. Fierce protest on the part of fishermen, eel smokers and dealers, who claimed to lose their living, did not lead to alteration of this Ministerial decision. 
What has been the result? It took a few years of adaptation to the new situation. The fishermen soon learned to catch immature eels with other gear than trawl nets: hooks and line, in use long since, baited wooden eel boxes and series of special fyke-nets set on the bottom. After some years the silver eel catches showed a spectacular recovery which soon led to great prosperity among the fishermen operating with fyke-nets on the migration routes. Full protection of juvenile specimens of perch and pike-perch led to a spectacular increase in the catches of these species, welcome on the market in several countries. An explosive reproduction of the ruff, feared by the fishermen, did not occur. The whole fishery of Lake IJssel prospered again, even decidedly better than ever before, and the fishermen soon forgot their fierce protestation against the drastic changes in the fishery pattern. An unexpected result was much faster growth of the immature eels, which now reach the stage of silver eels in fewer years than before. It is surmised that removal of the disturbance produced by the trawl nets must have led to more peaceful conditions on the bottom of the lake and therefore to better growth of the eels; but for the time being this explanation is only a working hypothesis. Lake IJssel now brings higher proceeds than ever before, the only worry left being the influx of heavy metals, phenols and chlorinated hydrocarbons via the River IJssel, but the faster the growth of the fish, the shorter the time available for accumulation of those obnoxious pollutants in their flesh.

Many things happened since the year 1932 in the Lake IJssel fishery, and finally all turned out well, but is there any reason to claim that this favourable outcome is due to wise fishery management?

\section{CONCLUSIONS}

The examples discussed can only lead to the conclusion that the type of management observed in industrial enterprises ashore does not find its equivalent in the fishing industry, though all the ingredients for sound management seem to be available. In reality the present situation is rather chaotic in the north-eastern Atlantic area, despite the efforts by the "Permanent Commission for the Overfishing of the North Sea," followed by the "North-East Atlantic Fisheries Commission", operating in a larger area. The proclamation of a 200-mile zone by countries or groups of countries has thus far not led to a real improvement of the situation, that is, to a better approach of rational exploitation of natural marine resources.

Why is it so very difficult to persuade the fishing industry to accept sound management? Most probably, the general mentality of those engaged in it, which differs considerably from that prevailing in industrial enterprises ashore, has a role to play. In broad terms, one could say that the fishery is not thinking in terms of consolidating its enterprises on a long-term basis, but is more interested in quick profit. Fishermen are not investors, but adventurers challenged by the presence of fish in the sea, in the lakes and in the streams, taking appropriate actions to catch at short notice as much of it as they possibly can. Good management, on the other hand, would require foresight and longterm planning of the exploitation of the natural resources. The scientists in the working groups of the "International Council for the Exploration of the Sea" assess the fluctuations in the stocks of fish of commercial importance and warn the North-East Atlantic Fisheries Commission when overfishing threatens or is already evident. They then know 
that the best remedy would be to stop fishing on the stock concerned to offer it a chance to revive, but realize that such will be hard to accept by the fishing industry which has invested so much money in its fleet, and wishes to supply its market without interruption. Therefore, they advise as next best measure a less drastic reduction in the fishing intensity, which may also lead to revival of the stock, but then of course in the longer term. The crucial point is that the fishing industry is interested in what happens in the present, but cannot accept a really drastic reduction of its activities, whereas a slow revival would require many years and hence they have hardly any interest in so remote an improvement. The fishing industry is very well aware of the advice of the fishery scientists, but just hopes that they may have been too pessimistic in their assessments. It has even been said that the quotas computed by the scientists of the Council have purposely been set too low since one realized that the various international fishery industries would not be satisfied with the quota suggested and would insist on adding an appreciable tonnage to it! It is easy to appreciate how much frustration such an unrealistic and ridiculous assumption will cautse in the world of scientists.

Still, there is no need for despair. The fertility of the aquatic environment, and above all of the North Sea, is hardly affected by the fishery. In spite of all the activities of the fishing industry the North Sea can yield year after year some two to three million tons of fish. If the fishing industry continues to overfish the commercially most valuable species one will observe an almost automatic increment in the stocks of species of lesser commercial value such as sand-eels (Ammodytes sp.), sprat (Clupea sprattus) and Norway pout (Gadus esmarkii). Such low-grade species, rightly called the opportunists among the fishes, can be used by the industrial fishery. The total tonnage landed from a fertile sea like the North Sea will not decline as a consequence of too intensive fishing, but the proceeds will drop considerably if the fishing industry is not really willing to accept sound management of the natural resources. We have two choices: to strive for good management to approach as closely as possible the optimum sustainable profit, or to lose the high-grade fish and to exploit the low-grade species for the fish-meal industry. It is up to the international fishing industry to make this choice, for coexistence of the traditional fishery for human consumption with a large-scale industrial fishery in the very same area seems hardly possible, unless one manages to develop fishing techniques which ensure a really "clean" catch, devoid of by-catches. We should realize, however, that - should the choice be in favour of industrial fishery - considerably less animal protein will come from the aquatic environment to man's tables than in the case of a decision to fish for direct human consumption.

\section{LITERATURE CITED*}

\section{The oyster}

Korringa, P., 1976. Farming the flat oysters of the genus Ostrea. Amsterdam, Elsevier, 238 pp.

Möbius, K., 1870. Ueber Austern- und Miesmuschelzucht und die Uebung derselben an den norddeutschen Küsten. Wiegandt \& Hempel, Berlin.

Orton, J. H., 1937. Oyster biology and oyster culture being the Buckland lectures for 1935. Arnold, London.

Yonge, C. M., 1966. Oysters. Collins, London.

* The sections indicated have been written on the basis of the literature listed 
The blue mussel

Bayne, B. L. (ed.), 1976. Marine mussels their ecology and physiology. Cambridge Univ. Press, Cambridge, $506 \mathrm{pp}$.

Havinga, B., 1929. Krebse und Weichtiere. - Handb. Seefisch. Nordeur. 3 (2), 1-147.

Havinga, B., 1932. Austern- und Muschelkultur. - Handb. Seefisch. Nordeur. 7, 1-64.

Korringa, P., 1976. Farming marine organisms low in the food chain. Amsterdam, Elsevier, 264 pp.

The brown shrimp

Besancon, H. C., 1973. Review of the developments of the selective shrimp trawl in the Netherlands - F.A.O. Fish. Rep. 139, 21-24.

Boddeke, R., 1965. Een beter garnalennet. - Viss. Nieuws 18, 2-8.

Boddeke, R., 1968. A new shrimp sieve. - C.M.-I.C.E.S. B 12.

Boddeke, R., 1973. Development in the Dutch shrimp (Crangon crangon) fisheries. - F.A.O. Fish. Rep. 139, 16-20.

Boddeke, R., 1975. Changes in the stock of brown shrimp (Crangon crangon L.) in the coastal area of the Netherlands. ICES symposium on the changes in the North Sea fish stock and their causes. Aarhus, 37 .

Boddeke, R., \& Verbaan, A., 1976. Het mechanisch transport voor de spoelsorteermachine. - Visserij $29,386-396$.

Korringa, P., 1969. Shellfish of the North Sea. In: Serial atlas of the marine environment. Ed. by W. Webster. Am. Geogr. Soc., New York.

Korringa, P., 1973. The edge of the North Sea as nursery ground and shellfish area. In: North Sea Science. Ed. by E. D. Goldberg. MIT Press, Cambridge, Mass., 361-382.

Veen, J. F. de, 1972. Tagging experiments with juvenile soles in the Dutch nursery areas in 1968, 1969 and 1970 - C. M.-I.C.E.S. F 46.

Zijlstra, J. J., 1972. On the importance of the Waddensea as a nursery area in relation to the conservation of the southern North Sea fishery resources. - Symp. zool. Soc. Lond. 29, 233-258.

The sole

Veen, J. F. de, 1965. De beste wensen met het nieuwe tongjaar. - Visserijwereld 24 (51/52), 42-44.

Veen, J. F. de, 1967. Zitten wij goed met de tong? - Visserij, 20, 170-174.

Veen, J. F. de, 1970. De tongvisserij internationaal bezien. - Visserij 23, 378-383.

Veen, J. F. de, 1970. Moeilijke tijden voor de tongvisserij. - Visserijwereld 29 (51), 1-3.

Veen, J. F. de, 1972. Gevolgen van opvoeren motorvermogen voor de tongstand. - Visserijwereld $31(20) 1-3$.

Veen, J. F. de, 1973. Overbevissing I. - Visserij 26, 55-74.

Veen, J. F. de, 1973. Overbevissing II. Het effect van maaswijdteverandering. - Visserij 26, $410-420$.

Veen, J. F. de, 1974. Overbevissing III. Het effect van gesloten gebieden voor de tongvisserij. Visserij 27, 5-22.

Veen, J. F. de, 1975. Changes in the North Sea sole stocks. ICES symposium on the changes in the North Sea fish stocks and their causes. - Aarhus, 30 .

Veen, J. F. de, 1976. On changes in some biological parameters in the North Sea sole (Solea solea L.). - J. Cons. int. Explor. Mer. 37, 60-90.

Veen, J. F. de, 1976. On the exploitation pattern in the Dutch North Sea sole fishery - C.M.-I.C.E.S. F 19.

Veen, J. F. de, 1976. Vooruitzichten in de Nederlandse visserij op platvis. I. De tongvisserij. Visserij, 29, 67-84.

Veen, J. F. de, 1976. Vooruitzichten in de Nederiandse visserij op platvis. 3. Het exploitatie-patroon van de tongvisserij: gesloten gebieden en maaswijdte. - Visserij 29, 479-493.

Veen, J. F. de, 1976. De visserij in moeilijkheden. - Rabobank 5 (8), 14-17.

The herring

Anonymous, 1977. Report of the herring assessment working group for the area south of $62^{\circ}$ N. - C.M.-I.C.E.S. H 3. 
Burd, A. C., 1973. Recruitment to the North Sea herring stocks. - C.M.-I.C.E.S. H11.

Burd, A. C., 1975. Long-term changes in North Sea herring stocks. ICES Symposium on the changes in the North Sea fish stock and their causes. - Aarhus, 16.

Postuma, K. H., \& Zijlstra, J. J., 1974. Larval abundance in relation to stock size, spawning potential and recruitment in North Sea herring. In: The early life history of fish. Ed. by J. H. S. Blaxter. Springer, Berlin, 113-128.

Saville, A., 1975. Growth of herring in the northwestern North Sea and some comments on herring larval distribution and abundance. ICES Symposium on the changes in the North Sea fish stock and their causes. - Aarhus, 43.

The salmon of the River Rhine

Anonymous, 1916. Verslag van de Staatscommissie voor het Zalmvraagstuk. Algemeene Landsdrukkerij te 's-Gravenhage, 1, 1-91; 2, 1-273.

Boddeke, R., 1971. Vissen en vissen. Elsevier, Amsterdam, 224 pp.

Deelder, C. L., \& Drimmelen, D. E. van, 1959. The decline of the fish-stocks in the Netherlands sections of the rivers Rhine and Meuse. Athens Proc. I.U.C.N. tech. Meet. 4, 185-190.

Groot, S. J. de, \& Schaap, S., 1973. De Nederlandse visserij rond 1900. Van Kampen, Amsterdam, $176 \mathrm{pp}$.

Lobregt, P., \& Os, J. van, 1977. De laatste riviervissers. Stichting Riviervisserij Nederland, Heerewaarden, $131 \mathrm{pp}$.

The bowhead whale

Matthews, L. Harrison (ed.), 1968. The Whale. Allen \& Unwin, London, 287 pp.

Mooy, H., 1942. Naar Groenland met de Frankendaal. Historisch verhaal naar het journaal van Commandeur Maarten Mooy. Wereldbibliotheek, Amsterdam.

Slijper, E. J., 1958. Walvissen. Centen, Amsterdam, 523 pp.

From Zuyder Sea to Lake IJssel

Anonymous, 1966. Rapport inzake de IJsselmeervisserij. Voorlopige Adviesraad voor de Visserij op het IJsselmeer; Report to the Minister of Agriculture and Fisheries.

Deelder, C. L., 1951-1957. Onderzoekingen omtrent de trek van de glasaal naar het IJsselmeer. Driemaandelijks Bericht betreffende de Zuiderzeewerken $32,5-7 ; 33,155-156 ; 35,117-119 ; 37$, $156-158 ; 38,150-151$.

Deelder, C. L., 1956. Over het verband tussen glasaalintrek en schieraalvangsten van het IJsselmeer, - Viss.-Nieuws 9, 24.

Deelder, C. L., 1957. De glasaalintrek bij de Afsluitdijk. - Land en Water 1957, 200-201.

Deelder, C. L., 1958. On the behaviour of elvers migrating from the sea into fresh water. - J. Cons. perm. int. Explor. Mer 24, 135-146.

Deelder, C. L., 1959. Conservation of elver migration routes into the inland water-system of the Netherlands. - Athens Proc. I.U.C.N. tech. Meet. 4, 321-322.

Deelder, C. L., 1960. Ergebnisse über den holländischen Untersuchungen über den Glasaalzug. Arch. FischWiss. 11, 1-10.

Deelder, C. L., 1963. Enkele aspecten van de tegenwoordige IJsselmeervisserij. - Rep. Min. Agric. Fish. 1963, 1-30.

Deelder, C. L., 1965. The influence of increased fishing-intensity on an eelstock. - Proc. Brit. Coarse Fish Conf. Liverpool 2, 57-64.

Deelder, C. L., 1968. Nota betreffende het Rapport inzake de IJsselmeervisserij. - Rep. Min. Agric. Fish. 1968, 1-27.

Deelder, C. L., 1976. Veranderingen in the groeipatroon van IJsselmeeraal. - Visserij 29, 403-405.

Deelder, C. L., \& Veen, J. F. de, 1958. A calculation on the fishing-intensity of the eeltrawl on the IJsselmeer and on the effect of an increase of the legal minimum size for eels. - Archs néerl. Zool. 13 (Suppl.), 461-471.

Havinga, B., 1945. Rapport betreffende de Visscherij en den Vischstand op het IJsselmeer en de maatregelen tot verbetering van de productiviteit. - Report to the Voorzitter van de Generale Commissie Zuiderzeesteunwet, $114 \mathrm{pp}$. 
Korringa, P., Deelder, C. L. \& Willemsen, J., 1970. De kuilvisserij op het IJsselmeer. - Visserij 23, 53-65.

Redeke, H. C., 1907. Rapport over onderzoekingen betreffende de Visscherij in de Zuiderzee in de jaren 1905 en 1906. Ministerie van Landbouw, Nijverheid en Handel, 's-Gravenhage, 91 pp.

Schaper, A., 1962. De IJsselmeervisserij. Thesis, Univ. Amsterdam, 164 pp.

Ypma, Y. N., 1962. Geschiedenis van de Zuiderzeevisserij. Thesis, Univ. Amsterdam, 223 pp. 